\title{
Factors Affecting Health Worker Anxiety in Covid-19 Prevention at Murni Teguh Memorial Hospital
}

\author{
Lilies Lingkaran ${ }^{1 *}$, Sri Lestari Ramadhani Nasution², Ermi Girsang ${ }^{3}$, Chrismis \\ Novalinda Ginting ${ }^{4}$ \\ ${ }^{1}$ Magister Student of Magister Public Health, Faculty of Medicine, University of Prima \\ Indonesia \\ ${ }^{2,3,4}$ Magister Public Health, Faculty of Medicine, University of Prima Indonesia \\ ${ }^{*}$ Corresponding author: \\ Email: liliesunpri@gmail.com
}

\begin{abstract}
.
The incidence of Covid-19 is a pandemic that has hit the whole world. Health workers who treat Covid-19 patients are a group with a very high risk of exposure. The psychological response experienced by health workers to infectious disease pandemics is increasing because it is caused by feelings of anxiety. This study analyzes what factors influence the anxiety of health workers in preventing Covid-19 at Murni Teguh Memorial Hospital. This research is a quantitative analytic study with a cross sectional approach. The research population is health workers who are limited to doctors and nurses who are tasked with preventing, handling and caring for Covid-19 patients in the emergency room installation and isolation room at Murni Teguh Memorial Hospital Medan. Samples were taken using the Taro Yamane formula as many as 61 people. Methods of data collection through the distribution of questionnaires and documentation. The data analysis method consisted of univariate, bivariate and multivariate using multiple logistic regression equations. The results of the study showed the influence of workload, community stigma, family status, knowledge and availability of personal protective equipment (PPE) for health workers' anxiety in preventing Covid-19 in the Emergency Room and Pure Isolation Room of Teguh Memorial Hospital. The conclusion of the study is that the factors that influence the anxiety of health workers are workload, community stigma, family status, knowledge about Covid-19 prevention and the availability of PPE and workload is the dominant variable affecting the anxiety of health workers.
\end{abstract}

Keywords: Influencing Factors, Anxiety, Health Workers, Covid-19 Pandemic

\section{INTRODUCTION}

The first known cases of the disease COVID-19 emerged in the Huanan Seafood Market neighborhood in Wuhan and animal-to-human transmission is considered to be the main mechanism. Subsequent cases of COVID-19 disease, however, are not 
associated with this mechanism of exposure. Therefore, it can be said that the virus can also be transmitted from human to human and people who have symptoms are the source of the spread of COVID-19. Due to the possibility of transmission before symptoms occur, asymptomatic individuals can transmit the virus, so isolation is the best way to contain this epidemic (Guo et al., 2020).

This direct human-to-human transmission has resulted in an extraordinary increase in the number of cases, until at the end of January 2020 there was an increase of 2000 confirmed cases in 24 hours. At the end of January 2020 WHO declared a Global Emergency status for this Corona virus case and on February 11, 2020 WHO named it COVID-19 (WHOa, 2020). According to the World Health Organization (Wealth Health Organization or WHO) on April 6, 2020, the number of people infected with Covid-19 worldwide was 1,278,523 people. The first positive case of Covid-19 in North Sumatra Province was confirmed on March 21, 2020, from people who had just returned from traveling from abroad. Over time, as of June 30, 2020, 1,551 positive cases have been recorded. 405 people $(26,1 \%)$ of them have been declared cured, and 92 people (5.9\%) died.

The impact of the Covid-19 pandemic has caused many losses such as physical health disorders, economic inequality, social inequality and mental disorders (Wang et al. 2020). Mental disorders that occurred during the Covid-19 pandemic were anxiety, fear, stress, depression, panic, sadness, frustration, anger, and denial (Huang et al. 2020). The psychological response experienced by health workers to infectious disease pandemics is increasing because it is caused by feelings of anxiety about one's own health and the spread of the family (Cheng et al., 2020). According to the IASC (2020) the causes of health workers experiencing anxiety are high job demands, including long working hours, the number of patients is increasing, it is increasingly difficult to get social support due to community stigma against front-line officers.

Fadli et al's research (2020) found that there was an influence of age, family status, patient honesty, availability of personal protective equipment and knowledge on officer anxiety. The variable availability of personal protective equipment that has the most influence on anxiety. Handayani et al's research (2020) found that the risk factors for anxiety include: sociodemographic, high working hours, stigma, and fears of being exposed to Covid-19. The research of Cheng et al. (2020) stated that out of 13 participants experienced anxiety because protective supplies had not been met when taking action to patients. The results of the initial survey at the research location, namely at Murni Teguh Memorial Hospital, it is known that in general health workers, both doctors, nurses, midwives and other health workers experience anxiety every time they carry out their duties. Based on the results of interviews through questionnaires with 12 health workers, it is known that health workers feel anxious because of fear of contracting or transmitting Covid-19 to their families. Health workers on average have good knowledge about Covid-19 and know what efforts must be made to prevent it, including using personal protective equipment (PPE). In fact, some health workers said 
they encountered various obstacles in their efforts to prevent Covid-19, including incomplete PPE available, inadequate PPE storage so that there was often a buildup of PPE that could allow cross contact and the repetition of PPE use such as face shields. Other obstacles related to the use of PPE while on duty are feeling short of breath, stuffy, hot and tired and often holding back thirst and hunger (Survey Results, 2020).

\section{METHODS}

This type of research is quantitative analytic with a cross sectional approach. According to Notoatmodjo (2018), the cross sectional approach is a study to study the dynamics of the correlation between risk factors and effects, by approaching, observing or collecting data all at once. This study aims to explain the relationship or influence between the variables studied.

This research was conducted at Murni Teguh Memorial Hospital Medan in April 2021. The reason for choosing the research location is because this hospital is one of the referral hospitals for Covid-19 patients.

The population in this study is health workers who are limited to doctors and nurses who are tasked with preventing, handling and caring for Covid-19 patients in the emergency room installation and isolation room at Murni Teguh Memorial Hospital Medan. The total population is 154 people, consisting of 5 Internal Medicine Specialists, 5 Lung Disease Specialists, 22 General Practitioners and 122 Nurses. The number of samples was 61 people consisting of 2 Internal Medicine Specialists, 2 Lung Disease Specialists, 9 General Practitioners and 48 Nurses. The research data were processed using the SPSS 20.0 for Windows Statistical Base Program.

\section{RESULT AND DISCUSSION}

The results showed that the majority of health workers who served in the Emergency Room and Isolation Room of Teguh Memorial Hospital Medan had a heavy workload (65.6\%). This can be seen from the answers of the respondents, the majority of whom stated that the work provided was not in accordance with the abilities and skills of health workers, the work given to health workers exceeded the actual portion so that it made health workers feel overwhelmed in serving patients and the existing work made health workers have to work as quickly as possible. possible and feel a race in time.

Based on the results of the multiple logistic regression test of the workload variable, the $p$ value $=0.015<0.05$ means that there is an effect of workload on the anxiety of health workers in the Emergency Unit Room and the Pure Isolation Room at Teguh Memorial Hospital Medan. In other words, the lighter the workload, the less/moderate anxiety of health workers will be. However, there were still 69 health workers with severe anxiety, this could be due to an unsupportive work situation, such as during the Covid-19 pandemic, patients became crowded, the fear of infection from Covid-19 patients and the number of health workers was still lacking compared to the 
number of Covid-19 patients. 19 that require maximum service. The number of Covid19 patients who must be treated because this hospital is a referral hospital for Covid-19 patients, this hospital accepts BPJS card holder patients and this private hospital is located in the city center so it is easy to reach. The results of this study are in line with the research of Solon et al (2021) who found that the workload of nurses can affect the stress level of nurses during the Covid 19 pandemic. Research by Setyowati and Ulfa (2020), identified a relationship between workload and work environment on the work stress of the Traffic Police unit. Bantul Yogyakarta Police who stated that the presence of an excessive job description can cause physical and mental workloads.

The results showed that the majority of health workers who served in the Emergency Room and the Pure Isolation Room of Teguh Memorial Hospital Medan stated that they faced stigma from the community (59\%) which tended to be negative. The results also show that there is an influence of community stigma on the anxiety of health workers in the Emergency Room and the Pure Isolation Room at Teguh Memorial Hospital Medan. This is based on the statement of health workers that during the Covid-19 pandemic, people gave negative stigma to health workers, such as being considered as carriers of the virus because they worked in hospitals, especially if someone around them had a sudden fever. people tend to look down on health workers and tend to avoid seeing health workers in an environment that is marked quickly by the hospital uniforms that health workers wear. The results of this study are in line with research by Mohindra, Suri, Bhalla, Singh (2020) who found one of the factors that caused anxiety in health workers in the era of the C-19 pandemic, namely stigma from the community as a source of infection. Handayani et al (2020) research found that one of the risk factors for anxiety in health workers is the stigma that has concerns about being exposed to Covid-19 from health workers. Azimah's research (2021) found that during the COVID-19 pandemic, health workers did not escape stigma in the form of intrapersonal and interpersonal stigma.

The results showed that the majority of health workers who served in the Emergency Room and Isolation Room of Teguh Memorial Hospital Medan were married (55.7\%). The results of this study are in line with the research of Zhou et al. (2020) found factors that caused anxiety in health workers in the era of the C19 pandemic, one of which was sociodemographic characteristics from the aspect of marital status.

The results showed that the majority of health workers who served in the Emergency Room and Isolation Room of Teguh Memorial Hospital Medan had a good level of knowledge $(52.5 \%)$. This is because the average level of education is a bachelor's degree (S2, profession and the lowest is D-3 nursing). The results showed that there was an influence of knowledge about the prevention of Covid-19 and PPE on the anxiety of health workers in the Emergency Room and the Pure Isolation Room of Teguh Memorial Hospital Medan. The results of this study are in line with Fadli's research $(2020)$ which found that there was an effect of knowledge $(p=0.030)$ on the 
anxiety of health workers. Research by Vindegaard and Benros (2020) found that one of the factors causing anxiety in health workers in the era of the C-19 pandemic was lack of knowledge about the pandemic.

The results showed that the majority of health workers on duty in the Emergency Room and Isolation Room of Teguh Memorial Hospital Medan stated that the availability of PPE was sufficient (54.1\%) to support the smooth running of tasks and protect themselves from contracting or transmitting the Covid-19 virus. The results of this study also indicate that there is an effect of the availability of PPE on the anxiety of health workers in the Emergency Room and the Pure Isolation Room of Teguh Memorial Hospital Medan. The results of this study are in line with the research of Kusumaningsih et al., (2020) which states that the workload that increases during the pandemic period for health workers is physical workload, then continued with the use of Personal Protective Equipment (PPE) which affects the performance of health workers so that they must carry out work that exceeds capacity and increases the mental burden felt by health workers.

\section{CONCLUSION}

This study concludes that there is an influence of workload, community stigma, family status, knowledge and availability of PPE on the anxiety of health workers in preventing Covid-19 in the Emergency Room and Isolation Room of MurniTeguh Memorial Hospital and workload is the dominant variable affecting anxiety health workers.

\section{ACKNOWLEDGMENTS}

Thank you to the supervisor who has guided to complete this research. And we don't forget to thank the family for the great support to the author.

\section{REFERENCES}

[1] Guo, Y., Cao, Q., Hong, Z., Tan, Y., Chen, S., Jin, H., Yan, Y. (2020). The Origin, Transmission and Clinical Therapies on Coronavirus Disease 2019 (COVID-19) Outbreak - an Update on the Status. Military Medical Research, 7(11), 1-10.

[2] WHO. (World Health Organization). (2020a). The World Health Organization declared the coronavirus outbreak a Global Public Health Emergency. Diakses tanggal 28 Desember 2019 dari https://www.worldometers.info/coronavirus/

[3] Wang, C. Pan, R. Wan, X Tan, Y. Xu, L. Ho, CS. Ho, R C. (2020) "Immediate psychological responses and associated factors during the initial stage of the 2019 coronavirus disease (COVID-19) epidemic among the general population in China ${ }^{\text {ee }}$ International Journal of Environmental Research and Public Health. doi: 10.3390/ijerph17051729. 
[4] Huang C, Wang Y, Li X, Ren L, Zhao J, Hu Y, et al. Clinical features of patients infected with 2019 novel coronavirus in Wuhan, China. Lancet (London, England) 2020;395(10223):497-506. doi: 10.1016/S0140-6736(20)30183- 5.

[5] Cheng, Q., Liang, M., Li, Y., He, L., Guo, J., Fei, D., Zhang, Z. (2020). Correspondence Mental health care for medical staff in China during the COVID-19. Lancet, 7, 15-26. https:// doi.org/10.1016/S2215-0366(20)30078-X.

[6] IASC. (2020). Catatan tentang Aspek Kesehatan Jiwa dan Psikososial Wabah Covid-19 (pp. 1-20).

[7] Fadli, Safruddin, Ahmad, Andi Sastria, Sumbara., dan Baharuddin, Rohandi. 2020. Faktor yang Mempengaruhi Kecemasan pada Tenaga Kesehatan dalam Upaya Pencegahan Covid-19. JPKI 2020 volume 6 no. 1.

[8] Handayani, R. T., Suminanto, Darmayanti, A. T., Widiyanto, A dan Atmojo, J.T. 2020. Kondisi dan Strategi Penanganan Kecemasan pada Tenaga Kesehatan Saat Pandemi Covid-19. Jurnal Ilmu Keperawatan Jiwa Volume 3 No 3, Hal 365 - 374, Agustus 2020.

[9] Solon, M., Madu, Y.G., Tolidunde, M dan Megawati. (2021). Dampak Beban Kerja Terhadap Tingkat Stres Pada Tenaga Kesehatan Selama Masa Pandemi Covid 19. Jurnal Keperawatan Florence Nightingale (JKFN) Vol. 4, No. 2, Desember 2021, pp. 94-101.

[10] Setyowati, R., \& Ulfa, S. M. (2020). Hubungan Beban Kerja dan Lingkungan Kerja Terhadap Stres Kerja Pada Polisi Satlantas Polres Bantul The Correlation Between Workload and Work Environment towards the Work STIKes Surya Global Yogyakarta. 169-178.

[11] Mohindra, R., Ravaki, R., Suri, V., Bhalla, A., \& Singh, S. M. (2020). Issues relevant to mental health promotion in frontline health care providers managing quarantined/isolated COVID19 patients. Asian Journal of Psychiatry, 51, 102084.

[12] Azimah, A.H.A. (2021). "Stigma terhadap Petugas Kesehatan Selama Pandemi Novel Coronavirus Disease (Covid-19): Literature Review”. Makassar: Fakultas Keperawatan Universitas Hasanuddin.

[13] Zhou, S. J.Yang, Zhang, Xu, Dou, Zhang, Chen, Cheng (2020) „Prevalence and sociodemographic correlates of psychological health problems in Chinese adolescents during the outbreak of COVID-19 ${ }^{\text {ee }}$ European Child and Adolescent Psychiatry. doi: 10.1007/s00787-020-01541-4.

[14] Vindegaard, N., Benros, M.E. (2020). COVID-19 pandemic and mental health consequences: Systematic review of the current evidence. Brain, Behavior, and Immunity, $1-12$.

[15] Kusumaningsih, D., Gumawan. M. Ricko, Zainaro, M. A., \& Widiyanti, T. (2020). Hubungan Beban Kerja Fisik Dan Mental Perawat Dengan Penerapan Pasien Safety Pada Masa Pandemi Covid 19 Di Upt Puskesmas Rawat Inap Kabupaten Pesawaran. 2(2), 108 118. 